\title{
Soybean Cultivar and Foliar Fungicide Effects on Phomopsis sp. Seed Infection
}

\author{
J. A. Wrather, J. G. Shannon, and W. E. Stevens, University of Missouri-Delta Center, Portageville 63873; \\ D. A. Sleper, University of Missouri-Columbia, Columbia 65211; and A. P. Arelli, United States Department of Ag- \\ riculture-Agricultural Research Service, Jackson, TN 38301
}

\begin{abstract}
Wrather, J. A., Shannon, J. G., Stevens, W. E., Sleper, D. A., and Arelli, A. P. 2004. Soybean cultivar and foliar fungicide effects on Phomopsis sp. seed infection. Plant Dis. 88:721-723.

Phomopsis seed decay (PSD) caused by Phomopsis spp. can be severe when soybean seed producers in the southern United States use the early soybean production system (ESPS) to avoid late-July through early-September drought damage to soybean. The usefulness of this production system would be greater if developing seed could be protected from PSD by foliar application of fungicides or by planting Phomopsis spp.-resistant soybean lines. The objective of this research was to determine the affects of the fungicides benomyl and azoxystrobin applied to soybean, at various times, on percent Phomopsis spp. infection of seed in Asgrow 3834, a PSD-susceptible cultivar, and SS93-6012, a PSD-resistant soybean line, planted in mid-April. The percent Phomopsis spp. infection of Asgrow 3834 seed averaged over years was significantly less for the benomyl $\left(0.28 \mathrm{~kg}\right.$ a.i. ha $\left.{ }^{-1}\right)$ applied at R3 + R5 treatment (48.6\% seed infection) than the control $(52.8 \%$ seed infection $)$ and significantly greater for the azoxystrobin $\left(0.17 \mathrm{~kg}\right.$ a.i. ha $\left.{ }^{-1}\right)$ applied at R3 + R5 treatment (61.6\% seed infection) than the control (52.8\% seed infection). This method of managing PSD will not be acceptable to soybean growers. The percent of Phomopsis spp. infection of Asgrow 3834 seed averaged over years (52.8\% seed infection) was significantly greater than for line SS93-6012 (2.8\% seed infection). There were no differences in percent Phomopsis spp. infection of SS93-6012 seed between the control (2.8\% seed infection) and benomyl treatment (4.0\% seed infection). The most effective method for PSD management was to plant a resistant soybean line. Line SS93-6012 will be useful in breeding programs focused on developing high yielding PSD-resistant cultivars.
\end{abstract}

The primary cause of Phomopsis seed decay (PSD) is Phomopsis longicolla T. W. Hobbs, but other species may be involved (11). This disease is endemic throughout most soybean-growing states in the United States (11), but incidence and severity of this disease varies among years and among regions (16) of the United States due to differences in weather at harvest. PSD is greater when harvest is delayed due to wet weather or when seed mature during midto late summer rather than in early fall (15).

Some soybean growers in the southern United States have adopted a soybean production system that results in seed maturing during mid- to late summer. This system, early soybean production system (ESPS), was designed to help growers in the south avoid late-July through earlySeptember drought damage to soybean (4).

Corresponding author: J. A. Wrather

E-mail: wratherj@missouri.edu

This research was supported, in part, by the Missouri Agricultural Experiment Station. This project also was supported by the Missouri Soybean Farmer Checkoff through the Missouri Soybean Merchandising Council grant no. 99-185.

Accepted for publication 3 March 2004.

Publication no. D-2004-0503-01R

(C) 2004 The American Phytopathological Society
Success of this system is dependent on planting early-maturing cultivars (MG III to IV) earlier than normal (early- to lateApril rather than mid-May to mid-June), so that pod fill is mostly complete before late-summer droughts develop. Yield advantages of this system have been observed in Arkansas (7), Mississippi (4), and Texas (8).

Yield advantages for this system have been observed in southeast Missouri $(15,17)$, but only during years when rainfall is abundant. Unfortunately, PSD was severe in some MG III and IV cultivars planted during mid-April in Arkansas (7) and Missouri $(15,17)$. This disease has suppressed yield, reduced the quality of seed used for planting (by reduced seed germination), and lowered the quality of seed used for processing $(10,15)$. The quality of oil derived from seed infected with Phomopsis spp. was lower than that from healthy seed (5), due to altered palmitic, oleic, linoleic, and linolenic acid composition (17). Usefulness of ESPS would be greater if seeds could be protected from PSD either by foliar application of fungicides or by planting resistant cultivars. Unfortunately, PSD-resistant cultivars currently are not commercially available.

Foliar applications of some rates of benomyl to soybean at various growth stages have reduced the percentage of seed infected by Phomopsis spp. and Diaporthe phaseolorum var. sojae (S. G. Lehman)
Wehmeyer. Tekrony et al. (14) and Ellis et al (2) determined that a single, R6 (3) application of benomyl $(0.28$ or $0.56 \mathrm{~kg}$ a.i. $\mathrm{ha}^{-1}$ ) to soybean foliage of soybean planted in mid-May reduced the percent of Phomopsis spp.- and D. phaseolorum var. sojae-infected seed, respectively, compared with controls. However, a single, R7 (3) application of benomyl ( 0.28 or 0.56 $\mathrm{kg} \mathrm{a.i.} \mathrm{ha}{ }^{-1}$ ) to foliage of soybean planted in mid-May did not reduce the percent Phomopsis spp. infection of seed $(6,14)$. Effects of foliar-applied fungicides on percent Phomopsis spp. infection of seed of early-planted (mid-April rather than mid-May), early-maturing soybean is not known. The objective of this research was to determine the affects of the fungicides benomyl and azoxystrobin applied to soybean foliage on percent Phomopsis spp. infection of mid-April-planted Asgrow 3834 seed, a PSD-susceptible cultivar, and SS93-6012, a PSD-resistant soybean line. Soybean line SS93-6012 was developed from a cross of a PSD-resistant line, MO/PSD-0259, and Asgrow 3322 (17). Benomyl currently is not labeled for use on soybean but was included in this study to provide some continuity with previously published reports. Azoxystrobin currently is labeled for foliar application to soybean.

\section{MATERIALS AND METHODS}

Experimental plot management. Plots for two experiments were established in 2000 and 2001 at a research center near Portageville, MO on a silt loam soil consisting of $56.5 \%$ sand, $37.2 \%$ silt, and $6.3 \%$ clay. The field had been planted to soybean during 1998 and 1999. One experiment (experiment 1) was designed to determine the effects of various application timings of benomyl and azoxystrobin to foliage on percent Phomopsis spp. infection of Asgrow 3834 seed. The second experiment (experiment 2) was designed to determine the effects of applications of benomyl and azoxystrobin to foliage at growth stages R3 and R5 on percent Phomopsis spp. infection of Asgrow 3834 and soybean line SS93-6012. The experiments were in the same field each year. Prior to planting each year, the field was disked twice, and row beds (75-cm spacing) were formed. The top $10 \mathrm{~cm}$ of the beds were pushed off just prior to planting to form a flat-top ridge. Soybean cv. Asgrow 3834 (MG III) and line SS 93-6012 (MG III) were planted on 21 April 2000 and 15 April 2001. Each four-row plot was $3 \mathrm{~m}$ 
Table 1. Analysis of variance for Phomopsis spp. infection of Asgrow 3834 for years and foliar fungicide treatments

\begin{tabular}{|c|c|}
\hline Source of variation ${ }^{\mathrm{z}}$ & $\begin{array}{c}P>F \\
\text { seed infected }(\%)\end{array}$ \\
\hline Year (Y) & 0.0089 \\
\hline Fungicide treatment $(\mathrm{T})$ & 0.0159 \\
\hline $\mathrm{Y} \times \mathrm{T}$ & 0.6906 \\
\hline
\end{tabular}

${ }^{2}$ Years were 2000 and 2001. Fungicide treatments were control (water only), benomyl $\left(0.28 \mathrm{~kg}\right.$ a.i. $\left.\mathrm{ha}^{-1}\right)$, and azoxystrobin $(0.17 \mathrm{~kg}$ a.i. ha ${ }^{-1}$ ) applied at various growth stages.

wide and $7.6 \mathrm{~m}$ long, and 26 seed were planted per meter of row. All plots received a pre-emergence application of imazaquin (BASF Corporation, Agriculture Products, Research Triangle Park, NC) at $0.14 \mathrm{~kg}$ a.i. $\mathrm{ha}^{-1}$ and alaclor (Monsanto Co., Agriculture Group, St. Louis) at $0.4 \mathrm{~kg}$ a.i. ha ${ }^{-1}$. Plots were cultivated twice and hand weeded each year as necessary. Plots were located in a different area of the same field each year to avoid problems caused by repeated planting in the same area. Plots were not irrigated. For experiment 1, a randomized complete block design with four replications and nine foliar fungicide treatments was used to evaluate the effects of timings of fungicides on Phomopsis spp. infection of Asgrow 3834 seed. For experiment 2, a split plot design was used with four replications, and included two cultivars as main plots and foliar fungicide treatments as subplots, to determine the effects of fungicides on Phomopsis spp. infection of Asgrow 3834 and SS93-6012 seed.

Fungicide application. Treatments were sprayed on plants at growth stages R3, R5, and R6 (3). The fungicides and rates applied were benomyl (Benlate, Dupont, Crop Protection Division, Wilmington, DE) at $0.28 \mathrm{~kg}$ a.i. $\mathrm{ha}^{-1}$ and azoxystrobin (Quadris, Syngenta Crop Protection, Inc., Greensboro, NC) at 0.17 $\mathrm{kg}$ a.i. $\mathrm{ha}^{-1}$. Treatments were applied in water with a $\mathrm{CO}_{2}$-powered handheld boom sprayer calibrated to deliver 187 liters ha ${ }^{-1}$ at $207 \mathrm{kPa}$.

Seed analysis. Each year, the middle two rows of each plot in each experiment were machine harvested at maturity. A 500 -g sample of harvested seed from each plot was stored in a paper bag at $25^{\circ} \mathrm{C}$ and analyzed within 30 days for percentage of seed infected with Phomopsis spp. One hundred arbitrarily chosen seed from each plot were surface disinfested in $0.5 \%$ sodium hypochlorite for $5 \mathrm{~min}$, rinsed in sterile distilled water, and placed on acidified ( $\mathrm{pH} 4.5)$ Difco potato dextrose agar in petri dishes (13). Five seed were placed on each culture dish and incubated under fluorescent lights at $25^{\circ} \mathrm{C}$. Seedborne fungi were identified based on morphological characteristics 7 days later $(1,11)$.

Data analysis. For both experiments, statistical analyses of fungicide treatment
Table 2. Foliar-applied fungicide effects on percent Phomopsis spp. infection of Asgrow 3834 seed averaged over years ${ }^{y}$

\begin{tabular}{|c|c|c|}
\hline Fungicides & $\begin{array}{c}\text { Time of } \\
\text { application }^{\mathrm{z}}\end{array}$ & $\begin{array}{c}\text { Seed } \\
\text { infected }(\%)\end{array}$ \\
\hline Control & & $52.8 \mathrm{~cd}$ \\
\hline Benomyl & R3 & $53.6 \mathrm{c}$ \\
\hline Benomyl & R5 & $50.6 \mathrm{de}$ \\
\hline Benomyl & R6 & $52.4 \mathrm{~cd}$ \\
\hline Benomyl & $\mathrm{R} 3+\mathrm{R} 5$ & $48.6 \mathrm{e}$ \\
\hline Azoxystrobin & R3 & $62.8 \mathrm{a}$ \\
\hline Azoxystrobin & R5 & $54.9 \mathrm{c}$ \\
\hline Azoxystrobin & R6 & $58.6 \mathrm{~b}$ \\
\hline Azoxystrobin & $\mathrm{R} 3+\mathrm{R} 5$ & $61.6 \mathrm{a}$ \\
\hline
\end{tabular}

${ }^{\mathrm{y}}$ Years were 2000 and 2001. Fungicides applied were control (water only), benomyl $(0.28 \mathrm{~kg}$ a.i. ha $\left.{ }^{-1}\right)$, and azoxystrobin $\left(0.17 \mathrm{~kg}\right.$ a.i. $\left.\mathrm{ha}^{-1}\right)$. Values followed by the same letter are not significantly different $(P=0.05)$

${ }^{\mathrm{z}}$ Fungicides were applied at R3 $(\operatorname{pod} 0.5 \mathrm{~cm}$ long at one of the four uppermost nodes with a completely unrolled leaf), R5 (beans can be felt when the pod is squeezed at one of the four uppermost nodes with a completely unrolled leaf), and R6 (pods containing full-size green beans at one of the four uppermost nodes with a completely unrolled leaf).

effects on percent Phomopsis spp. infection of Asgrow 3834 and SS93-6012 seed were performed using SAS Mixed Model procedures (SAS Institute, Cary, NC). The Mixed Model procedure provides type-III $F$ values but does not provide mean square values for each element within the analysis or the error terms. Mean separation was evaluated through a series of protected pairwise contrasts among all treatments (9). Probability levels greater than 0.05 were categorized as nonsignificant. Percent seed infected with Phomopsis spp. during 2000 and 2001 in the experiment with Asgrow 3834 and SS93-6012 was transformed before analysis $(X+0.5)^{1 / 2}$, where $X$ is the original percent infection (17), because the percent Phomopsis spp. infection of SS 93-6012 seed from all treatments was very low $(<10 \%)$ during both years. The letter grouping for the transformed means was applied to the original treatment means.

\section{RESULTS}

Analysis of variance for percent Phomopsis spp. infection of Asgrow 3834 seed indicated there was no year-fungicide treatment interaction (Table 1), but there was a year effect. The percent Phomopsis spp. infection of Asgrow 3834 seed, averaged over fungicide treatments, was significantly greater for $2001(61.1 \%)$ than for $2000(49.1 \%)$. There also was a fungicide treatment effect. The percent Phomopsis spp. infection of Asgrow 3834 seed averaged over years was significantly less for the benomyl applied at R3 + R5 treatment than the control, albeit differences were slight (Table 2). There were no differences in Phomopsis spp. infection of Asgrow 3834 seed among the other benomyl treatments and the control. The per-
Table 3. Analysis of variance for Phomopsis sp. infection of seed for years, cultivars, and foliar fungicide treatments

\begin{tabular}{lc}
\hline Source of variation & $\begin{array}{c}\boldsymbol{P}>\boldsymbol{F} \\
\text { seed }\end{array}$ \\
\hline infected (\%)
\end{tabular}

$\mathrm{z}$ Years were 2000 and 2001. Cultivars were Asgrow 3834 and soybean line SS 93-6181. Fungicide treatments were control, benomyl $\left(0.28 \mathrm{~kg}\right.$ a.i. $\left.\mathrm{ha}^{-1}\right)$, and azoxystrobin $(0.17 \mathrm{~kg}$ a.i. ha-1) applied at R3 + R5 growth stages where $\mathrm{R} 3=$ pod $0.5 \mathrm{~cm}$ long at one of the four uppermost nodes with a completely unrolled leaf and R5 = beans can be felt when the pod is squeezed at one of the four uppermost nodes with a completely unrolled leaf.

cent Phomopsis spp. infection of Asgrow 3834 seed averaged over years was significantly greater for azoxystrobin applied at $\mathrm{R} 3, \mathrm{R} 6$, and R3 + R5 than the control.

Analysis of variance for percent Phomopsis spp. infection of Asgrow 3834 and SS93-6012 seed indicated that there were significant cultivar-fungicide interactions (Table 3). The percent Phomopsis spp. infection of Asgrow 3834 seed was significantly greater for the control and azoxystrobin treatment than the benomyl treatment; moreover, infection of Asgrow 3834 seed was significantly greater than for line SS93-6012 (Table 4). There were no differences in percent Phomopsis spp. infection of SS93-6012 seed among fungicide treatments.

Analysis of variance for percent Phomopsis spp. of Asgrow 3834 and SS936012 seed infection also indicated that there was a significant year-cultivar interaction (Table 3). The percent Phomopsis spp. infection of Asgrow 3834 seed was significantly greater for 2001 than 2000 (Table 5). The percent Phomopsis spp. infection of Asgrow 3834 seed infected was significantly greater than for line SS 93-6012 both years.

\section{DISCUSSION}

Some benefits of ESPS have been shown in Arkansas (12), Mississippi (4), Texas (8), and Missouri $(15,17)$. Earlymaturing cultivars (MG III) planted in early to mid-April are ready for harvest about late-August to early September, and this is about 14 days earlier than for midMay plantings. Earlier harvest is an advantage for those growers who need to extend harvest over a longer period for more efficient use of labor and harvest machinery (15). Yield advantages for mid- to lateApril compared with mid-to late-May plantings of soybean have been reported from Texas (8), Mississippi (4), and some Missouri conditions (17), an obvious ad- 
Table 4. Cultivar and foliar fungicide treatment effects on percent Phomopsis sp. infection of Asgrow 3834 and line SS93-6012 seed averaged over years ${ }^{\mathrm{Z}}$

\begin{tabular}{lcc}
\hline & \multicolumn{2}{c}{ Seed infected (\%) } \\
\cline { 2 - 3 } Fungicide treatment & Asgrow 3834 & SS 93-6012 \\
\hline Control (water only) & $52.8 \mathrm{~b}$ & $2.8 \mathrm{~d}$ \\
Benomyl $\left(0.28 \mathrm{~kg} \mathrm{a.i.} \mathrm{ha}^{-1}\right)$ & $49.3 \mathrm{c}$ & $4.0 \mathrm{~d}$ \\
Azoxystrobin $\left(0.17 \mathrm{~kg} \mathrm{a.i.}^{-1}\right)$ & $62.9 \mathrm{a}$ & $3.4 \mathrm{~d}$ \\
\hline
\end{tabular}

$\mathrm{z}$ Years were 2000 and 2001. Fungicide treatments were applied at R3 + R5 growth stages. Values followed by the same letter are not significantly different $(P=0.05)$.

Table 5. Cultivar and year effects on percent Phomopsis sp. infection of seed averaged over foliar fungicide treatments ${ }^{\mathrm{z}}$

\begin{tabular}{lcc}
\hline & \multicolumn{2}{c}{ Seed infected (\%) } \\
\cline { 2 - 3 } Years & Asgrow 3834 & SS 93-6012 \\
\hline 2000 & $48.4 \mathrm{~b}$ & $3.1 \mathrm{c}$ \\
2001 & $61.6 \mathrm{a}$ & $3.7 \mathrm{c}$ \\
\hline
\end{tabular}

${ }^{\mathrm{z}}$ Foliar fungicide treatments were control (water only), benomyl $\left(0.28 \mathrm{~kg}\right.$ a.i. $\left.\mathrm{ha}^{-1}\right)$, and azoxystrobin $\left(0.17 \mathrm{~kg}\right.$ a.i. $\left.\mathrm{ha}^{-1}\right)$ applied at R3 + R5 growth stages. Values followed by the same letter are not significantly different $(P=$ $0.05)$.

vantage. Unfortunately, Phomopsis spp. infection of seed harvested from MG III cultivars planted in mid-April can be greater than for mid-May plantings $(7,15,17)$. Our results also showed that Phomopsis spp. infection of seed can be a problem for a susceptible cultivar (Asgrow 3834) planted in mid-April.

This is the first report on the effect of benomyl and azoxystrobin application to foliage of mid-April-planted MG III cultivars on percent Phomopsis spp. infection of seed. Benomyl at $0.28 \mathrm{~kg}$ a.i. ha ${ }^{-1}$ applied at R3 + R5 significantly reduced the percent infected seed compared with the control. However, averaged over 2 years, $48 \%$ of the seed of Asgrow 3834 treated with benomyl at R3 + R5 were still infected. Thus, this method of managing PSD will not be acceptable to soybean growers because none of the fungicide treatments tested provided practical levels of disease control.

Greater rates of benomyl, such as 0.56 $\mathrm{kg}$ a.i. ha ${ }^{-1}$, might have further reduced percent Phomopsis spp. infection of Asgrow 3834 seed than we observed with $0.28 \mathrm{~kg}$ a.i. ha ${ }^{-1}$. Tekrony et al. (14) determined that foliar application of benomyl at $0.56 \mathrm{~kg}$ a.i. $\mathrm{ha}^{-1}$ at R6 to May-planted soybean reduced percent Phomopsis spp. infection of seed more than $50 \%$ compared with the control. Jardine, however, showed that $0.28 \mathrm{~kg}$ a.i. ha ${ }^{-1}$ did not effect percentage of Phomopsis spp. seed infection compared with the control (6). In any event, benomyl is no longer labeled for use on soybean.

Soybean producers using the ESPS should be aware that foliar application of azoxystrobin to soybean foliage may be useful for management of some foliage diseases, but this product may increase the percent Phomopsis spp. seed infection. The reason some azoxystrobin treatments enhanced percent Phomopsis spp. infection of Asgrow 3834 seed compared with the control is not known. This product may interfere with the plant's natural defense mechanism to Phomopsis spp., or it may protect the plant from other diseases, thus extending the life of the plant so that Phomopsis spp. have more time to move through the pod and into seed.

Soybean growers need a high yielding, early-maturity cultivar that is resistant to PSD. Wrather et al. (17) were the first to report the successful management of this disease by planting early-maturing, PSDresistant soybean lines SS93-6012 and SS93-6181. Our data confirms that report about management of this disease by planting SS93-6012. Line SS93-6012 will be useful in breeding programs focused on developing high yielding Phomopsis seed decay-resistant cultivars.

Our plots were harvested when the crop was first mature. If harvest had been delayed, the percent Phomopsis spp. infection of SS93-6012 may have been greater.

\section{ACKNOWLEDGMENTS}

We thank J. Elrod for her efforts in this project and thank God for guidance.

\section{LITERATURE CITED}

1. Barnett, H. L., and Hunter, B. B. 1998. Illustrated Genera of Imperfect Fungi, 4th ed.
American Phytopathological Society, St. Paul, MN.

2. Ellis, M. A., Ilyas, M. B., Tenne, F. D., Sinclair, J. B., and Palm, H. L. 1974. Effect of foliar applications of benomyl on internally seed seedborne fungi and pod and stem blight in soybean. Plant Dis. Rep. 58:760-763.

3. Fehr, W. R., Caviness. C. E., Burmood, D. T., and Pennington, J. S. 1971. Stage of development descriptions for soybeans, Glycine max (L.) Merrill. Crop Sci. 11:929-931.

4. Heatherly, L. G. 1999. Early soybean production system (ESPS). Pages 103-118 in: Soybean Production in the Midsouth. L. G. Heatherly and H. F. Hodges, eds. CRC Press, Boca Raton, FL.

5. Hepperly, P. R., and Sinclair, J. B. 1978. Quality losses in Phomopsis-infected soybean seeds. Phytopathology 68:1684-1687.

6. Jardine, D. J. 1991. The Iowa soybean pod test for predicting Phomopsis seed decay in Kansas. Plant Dis. 75:523-525.

7. Mayhew, W. L., and Caviness, C. E. 1994. Seed quality and yield of early-planted, shortseason soybean genotypes. Agron. J. 86:16-19.

8. Savoy, B. R., Cothran, J. T., and Shumway, C R. 1992. Early-season production systems utilizing indeterminate soybean. Agron. J. 84:394398.

9. Saxton, A. M. 1998. A macro for converting mean separation output to letter groupings in Proc Mixed. Pages 1243-1246 in: Proc. 23rd Annu. SAS Users Group Inter. Conf. SAS Institute, Cary, NC.

10. Sinclair, J. B. 1993. Phomopsis seed decay of soybeans-a prototype for studying seed disease. Plant Dis. 77:329-334.

11. Sinclair, J. B. 1999. Phomopsis seed decay. Pages 31-32 in: Compendium of Soybean Diseases, 4th ed. G. L. Hartman, J. B. Sinclair, and J. C. Rupe, eds. American Phytopathological Society Press, St. Paul, MN.

12. Taylor, O. 1999. ESPS method moves north. Soybean Dig. 59:26-28.

13. Tekrony, D. M., Egli, D. B., Balles, J., Tomes, L., and Stuckey, R. E. 1984. Effect of date of harvest maturity on soybean seed quality and Phomopsis sp. seed infection. Crop Sci. 24:189-193.

14. Tekrony, D. M., Egli, D. B., Stuckey, R. E. and Loeffler, T. M. 1985. Effect of benomy applications on soybean seedborne fungi, seed germination, and yield. Plant Dis. 69:763-765.

15. Wrather, J. A., Kendig, S. R., Wiebold, W. J., and Riggs, R. D. 1996. Cultivar and planting date effects on soybean stand, yield, and Phomopsis sp. seed infection. Plant Dis. 80:622624.

16. Wrather, J. A., Koenning, S. R., and Anderson, T. R. 2003. Effect of diseases on soybean yield in the United States and Ontario (1999 to 2002). Online. Plant Health Progress doi:10. 1094/PHP-2003-0325-01-RV.

17. Wrather, J. A., Sleper, D. A., Stevens, W. E., Shannon, J. G., and Wilson, R. F. 2003. Planting date and cultivar effects on soybean yield, seed quality, and Phomopsis sp. seed infection. Plant Dis. 87:529-532. 